\title{
Evaluation of the Performance of Lowland Rice-ratooned Rice-vegetable as Influenced by Fertilizer Rates in Sawah Rice Systems
}

\author{
Adigbo, S. O. ${ }^{1}$, Wakatsuki, T. ${ }^{2}$, Fabusoro, E. ${ }^{3}$, Alarima, C. I. ${ }^{3}$, Alao, O. A. ${ }^{4}$, Odedina, J. N. ${ }^{4}$, \\ Adeyemi, O. R. ${ }^{4} \&$ Fabunmi, T. O. ${ }^{4}$ \\ ${ }^{1}$ Crop Research Programme, Institute of Food Security, Environmental Resource and Agricultural Research, \\ University of Agriculture, Abeokuta, Nigeria \\ ${ }^{2}$ School of Agriculture, Kinki University, Nara, Japan \\ ${ }^{3}$ Department of Agricultural Extension and Rural Development, University of Agriculture, Abeokuta, Nigeria \\ ${ }^{4}$ Department of Plant Physiology and Crop Production, University of Agriculture, Abeokuta, Nigeria \\ Correspondence: Adigbo, S. O., Crop Research Programme, Institute of Food Security, Environmental Resource \\ and Agricultural Research, University of Agriculture, Abeokuta, Nigeria. E-mail: sundayadigbo@yahoo.com
}

Received: September 20, 2012 Accepted: October 22, 2012 Online Published: December 13, 2012

doi: $10.5539 /$ jas.v5n1p181

URL: http://dx.doi.org/10.5539/jas.v5n1p181

\begin{abstract}
The trial was conducted at the Federal University of Agriculture; Abeokuta, Nigeria in 2010/2011 and 2011/2012 cropping season to evaluate the performance of lowland rice-ratooned rice-okra as influenced by fertilizer rates in sawah rice based system. Field was manually cleared and bunded but power tilled, puddled and leveled with inlet and outlet connections for irrigation and drainage. Fertilizer treatments evaluated on lowland rice were 90:45:45, 60:30:30, 45:22.5:22.5 and 30:15:15 NPK kg ha ${ }^{-1}$ whereas those of ratooned rice were $0,30,60$ and $90 \mathrm{~kg} \mathrm{~N} \mathrm{ha}^{-1}$. Grain yield, chlorophyll content and plant height at maturity of the main lowland rice were similar. The ratooned rice crop treated with $\mathrm{N}$-fertilizer had similar grain yield. The total grain yield of the two crops of rice ranged between 4.47 and $5.65 \mathrm{t} \mathrm{ha}^{-1} \mathrm{year}^{-1}$. The okra leaf chlorophyll content and okra pod weight obtained from the previous $\mathrm{N}$-fertilizer plot of 60 and $90 \mathrm{~kg} \mathrm{~N} \mathrm{ha}^{-1}$ were similar but significantly higher than those of 0 and $30 \mathrm{~kg} \mathrm{~N}$ $\mathrm{ha}^{-1}$. Thus, fertilizer combination of 30:15:15 kg NPK ha ${ }^{-1}$ for lowland rice and $60 \mathrm{~kg} \mathrm{~N} h a^{-1}$ for ratooned rice in sawah rice based production system enhanced the productivity of succeeding okra plant.
\end{abstract}

Keyword: sawah, fertilizer lowland rice, ratooned rice, okra

\section{Introduction}

Nigeria has the resource (abundant rainfed upland and inland valley) and management potential to produce enough rice to meet local and as well as for exportation (FAOSTAT, 2008). Ironically, Nigeria is the second largest importer of rice in the World after Philippine (Africa Rice Center, 2008). Therefore, improving the productivity of rice in the existing farming systems in the inland valleys is important for closing the gap between production and consumption. Land intensification via triple cropping, without irrigation, is a viable option for resource-poor farmers, who accounted for $75 \%$ rice production, to increase inland valley productivity.

In south west Nigeria, most farmers practice double cropping (lowland and vegetable or maize) in the inland valley. The utility of inland valley was further improved by increasing the crop intensification from two to three crops per year (Adigbo et al., 2007; Adigbo et al., 2010; Adigbo, 2012) without supplemental irrigation but the sustainability and judicious fertilizer utilization were not efficient. Therefore, there is the need to ascertain the productivity of the triple system in sawah based rice system which lay emphasis on the improvement of the rice environment.

Sawah refers to manmade improved rice growing environment with demarcated, bunded, puddled and leveled rice field with water inlets and outlets using power tillers for weed and water control in the inland valley which can be springs, or pump (Wakatsuki et al., 2005). The Sawah system of rice production ensures proper management of the rice environment leading to efficient and higher rice grains production with higher returns could be a better option to current systems (Wakatsuki \& Masuanga, 2005). 
It is well-known that weeds can be controlled by means of water control. But it has been documented that the nitrogen fixation by soil microbes under a submerged sawah systems could reach 20-100 kg/ha/year in Japan and $20-200 \mathrm{~kg} / \mathrm{ha} /$ year in the tropics depending on the level of soil fertility and water management (Kyuma, 2003; Hirose \& Wakatsuki, 2002). This amount is comparable to the nitrogen fixed by leguminous plants in upland ecology. Under submerged condition, because of reduction of ferric iron to ferrous iron, phosphorous availability is increased and acid $\mathrm{pH}$ is neutralized, hence micro-nutrients availability is also increased in sawah system (Kyuma, 2003). Given the above benefits accruable to sawah systems, there is the need to determine the minimum fertilizer requirement that will enhance the productivity of sawah. Besides, there is dearth information on the effects of the benefit derivable from sawah rice system on the performance of the succeeding ratooned rice crop vis-a-vis the influence of $\mathrm{N}$-fertilizer on the performance of ratooned . Furthermore, the residual effects of fertilizer applied to lowland rice-ratooned rice on succeeding okra crop during the dry season have not been determined. Oad and Ponpe (2001) examined the fertilizer response of ratooned rice and reported significant effect but did not include residual effect of applied fertilizer on the third crop in their investigation.

Rice ratooning is the practice of harvesting grain from tillers originating from the stubble of previously harvested lowland rice crop (main crop). It enhances rice grain yield without increasing land area because it provides higher resource use efficiency per unit land area per unit of time (Jason et al., 2005). Rice ratooning is one of the potential and attractive alternative technologies to increase rice production and reduce cost of production.

Okra (Abelmoschus esculentus) is a highly valuable fruit vegetable that commands high price during the dry season. Common okra is mainly grown for market gardening in areas with limited rainfall or under irrigation. There is need to evaluate this highly valued crop on residual effect of fertilizer in sawah rice based production system. The objectives of the study are to: 1) determine minimum fertilizer rate that will compliment the beneficial effects of sawah rice system, 2) evaluate ratooned rice responses to $\mathrm{N}$ - fertilizer in sawah systems and 3 ) examine the effects of lowland rice-ratooned rice sequence and fertilizer rates on the performance of okra.

\section{Materials and Methods}

The field experiment was carried out in 2010/2011 and 2011/2012 cropping seasons at the bottom of the inland valley of the Federal University of Agriculture Abeokuta in the forest savannah transition agro ecological zone of Nigeria. The total land area of 1.5 ha was cleared and divided into 112 sawah units based on topography with irrigation and drainage canals to irrigate the field and drain off excess water from the field, respectively. The area of the small plot sizes were determined by Global Positioning System (GPS). Bunds were manually constructed around each small unit plot to impound water from the irrigation canal. Power tiller was used to till, puddle and level the soil within each unit. The experiment was laid out in randomized complete block design in split plot arrangement in three replications. The seedlings were transplanted at spacing of $20 \mathrm{~cm}$ by $20 \mathrm{~cm} 3$ weeks after sowing in the nursery bed in May. Twelve plots of $11 \mathrm{~m} \mathrm{X} 4 \mathrm{~m}$ out of the 112 units were selected as main plot and were treated with NPK fertilizer at the following rates: 30:15:15, 45:22.5:22.5, 60:30:30, 90:45:45 $\mathrm{kg} \mathrm{ha}^{-1}$. After harvesting of the main lowland rice in September for both cropping seasons, the rice straws in the 12 plots were cut to about 5 to $10 \mathrm{~cm}$ above the soil surface to stimulate ratoon growth. The main plot was further divided into 4-sub plot of $4 \mathrm{~m} \mathrm{x} 2 \mathrm{~m}$ and the ratooned rice treated with $\mathrm{N}$-fertilizer at the rate of $0,30,60$ and $90 \mathrm{~kg} \mathrm{ha}^{-1}$. After harvesting of ratooned rice prior December, 2010 the standing ratooned rice straws were sprayed with herbicide and the dried rice straw became mulching material for okra plants. Ratooned rice crop of 2011/2012 was lost because harvesting of the main rice was delayed beyond necessary. Okra seeds were planted in late December into the sub plot to evaluate the residual effects of previous fertilizer applications to lowland rice and ratooned in 2010/2011 cropping seasons. However, the okra planted in 2011/2012 was based on residual effect of the preceding lowland rice and fallow because the ratooned crop failed arising from unduly delay in harvesting the lowland rice.

Only one weeding was done for main lowland rice whereas two weeding were carried out at 3 and 6 Weeks After Cutting (WAC) of lowland rice straw to stimulate ratooning. The panicles were harvested with the aid of knife when the panicles colour turned brown. Seed of okra were sown at two to three seeds per hole at inter-row and intra-row spacing of $80 \mathrm{~cm}$ and $30 \mathrm{~cm}$ respectively. Supplying and thinning were done at 7 days after sowing (DAS). Three weeding was carried out at 3, 6 and 10 weeks after sowing (WAS). Harvesting of fresh okra pods commenced 6 WAP and picking of fresh pod continues thereafter until March.

Data collection for lowland rice and ratooned rice included:

Chlorophyll content (greenness of rice leave): The leaf chlorophyll content was determined by using chlorophyll meter (model SPAD 502) to measure the lower, upper and the middle leaf. This was done for 5 randomly selected plants. 
Plant height (cm): This was done by measuring the plant height of 5 randomly selected plants with the aid of meter rule from the soil level to the tip of the longest leaf.

Panicle length $(\mathbf{c m})$ : Five mature panicles were randomly selected from each plot before harvest and their length were taken with the aid of ruler $(\mathrm{cm})$.

Panicle weight (gm): Five panicles were randomly selected from each plot and their weights were taken with the aid of sensitive scale in the lab which was divided by 5 .

Grain /panicle: Five panicles were randomly selected from each plot, threshed and grains were counted which was divided by 5 .

1000-grain weight (gm): 1000 seeds were counted from each plot and weighed.

Grain yields: The harvested panicles were sun dried, threshed, weighed and converted to $\mathrm{kg} / \mathrm{ha}$.

\section{Okra data included}

Plant height (cm): This was taken by using a meter rule to measure the 5 tagged plants from the ground level to the tips of the plant at 4,6,8 and 10 weeks after sowing (WAS).

Number of leaves: The number of leaves on each 5 tagged plants were counted and recorded at 4, 6, 8 and 10 WAS.

Number of branches: The number of branches on each 5 tagged plant was counted and recorded at 10 WAS.

Chlorophyll content: The chlorophyll content of the leaf was taken using chlorophyll content (SPAD) to measure the lower, upper and the middle leaf of the 5 tagged plants at $8 \mathrm{WAS}$.

Pod number: After each harvesting the number of pod were counted and recorded and the cumulative of the pod number was recorded.

Pod yield ( $\mathbf{k g} / \mathbf{h a})$ : The cumulative pod weights of all the harvest were recorded.

Data collected were subjected to analysis of variance (ANOVA) and treatment means that recorded significant difference were further separated using least significant different (LSD) at $5 \%$.

Table 1. Effects of fertilizer on lowland rice in sawah production system in the inland

\begin{tabular}{|c|c|c|c|c|c|c|c|c|c|c|c|c|}
\hline \multirow{3}{*}{$\begin{array}{l}\text { Fertiliz } \\
\text { er level }\end{array}$} & \multicolumn{2}{|c|}{$\begin{array}{c}\text { Chlorophyll } \\
\text { Before fertilizer }\end{array}$} & \multicolumn{2}{|c|}{$\begin{array}{c}\text { Chlorophyll } \\
\text { After } \\
\text { fertilizer }\end{array}$} & \multicolumn{2}{|c|}{$\begin{array}{l}\text { lant height at } 50 \% \\
\text { heading }(\mathrm{cm})\end{array}$} & \multicolumn{2}{|l|}{$\begin{array}{c}\text { Panicle } \\
\mathbf{m}^{-2}\end{array}$} & \multicolumn{2}{|c|}{$\begin{array}{l}\text { Panicle length } \\
\text { (cm) }\end{array}$} & \multicolumn{2}{|c|}{$\begin{array}{l}\text { Grain yield } \\
\quad\left(\mathrm{t} \mathrm{ha}^{-1}\right)\end{array}$} \\
\hline & $2010 / 2$ & $2011 / 2$ & $2010 / 20$ & $2011 / 20$ & $2010 / 2$ & $2011 / 20$ & $2010 / 2$ & $2011 / 20$ & $2010 / 2$ & $2011 / 20$ & $2010 / 2$ & $2011 / 2$ \\
\hline & 011 & 012 & 11 & 12 & 011 & 12 & 011 & 12 & 011 & 12 & 011 & 012 \\
\hline $\begin{array}{c}90: 45: 4 \\
5\end{array}$ & 36.1 & 36.95 & 41.2 & 42.72 & 143.7 & 147.0 & 158.3 & 193.7 & 27.3 & 29.67 & 4.03 & 4.49 \\
\hline $\begin{array}{c}60: 30: 3 \\
0\end{array}$ & 34.3 & 37.41 & 41.8 & 43.22 & 141.0 & 143.0 & 160.3 & 183.3 & 27.2 & 28.33 & 3.08 & 5.67 \\
\hline $\begin{array}{c}45: 22.5: \\
22.5\end{array}$ & 35.3 & 36.03 & 40.9 & 43.29 & 146.0 & 146.7 & 146.3 & 191.0 & 26.1 & 26.70 & 3.85 & 4.86 \\
\hline $\begin{array}{c}30: 15: 1 \\
5\end{array}$ & 35.8 & 34.25 & 41.5 & 41.69 & 141.0 & 149.7 & 141.0 & 186.7 & 26.5 & 27.33 & 3.82 & 4.77 \\
\hline LSD & 4.98 & 4.53 & 2.36 & 2.85 & 8.80 & 12.85 & 20.89 & 31.83 & 1.63 & 2.81 & 1.12 & 1.44 \\
\hline
\end{tabular}

\section{Results and Discussion}

Table 1 shows the effect of fertilizer levels on chlorophyll content of leaves, grain yield and yield component in both cropping seasons. The chlorophyll content of the leaf which is a measure of leaf greenness of the rice plant arising from the nutrient uptake was not influenced by the various fertilizer rates. Similarly, the plant height at $50 \%$ flowering obtained from the different fertilizer level was not significantly different from each other. But 2010/2011 cropping season had lower panicles $\mathrm{m}^{-2}$, panicle length and grain yield than 2011/2012. These consistent similarities in both cropping seasons were indications that sawah rice based production system has some in-built mechanism to fix nitrogen as well as enhance the availability of some plant nutrients that is lacking 
in the rainfed lowland rice. Generally, the targeted grain yield of $\geq 4 \mathrm{tha}^{-1}$ from sawah was attained particularly in 2011/2012.

There were several reports confirming the aforementioned paragraph on the ability of sawah technology to fix nitrogen, make phosphorous and other micronutrients available to rice plants. Nitrogen fixation by soil microbes under a submerged sawah systems which could reach 20-100 kg/ha/year in Japan and 20-200 kg/ha/year in the tropics depending on the level of soil fertility and water management (Kyuma, 2003; Hirose \& Wakatsuki, 2002). Furthermore, under submerged condition, reduction of ferric iron to ferrous iron, will make phosphorous available and acid $\mathrm{pH}$ is neutralized; hence micro-nutrients availability is also increased according to (Kyuma, 2003). Besides, the eutrophication mechanisms which encourage the growth of various algae that increase the nitrogen fixation could also contribute in part to the non-significance of the fertilizer that was applied to the lowland rice. Under nitrate rich submerged water conditions, sawah systems encourage denitrification, easily decomposable organic matter become substrate of various denitrifyers and purification of the nitrate polluted water (Kyuma, 2003; Hirose \& Wakatsuki, 2002).

These chemical processes occurring in sawah rice based production systems were likely to support the sustainability with minimal fertilizer application. The actual fertilizer recommendation for south Western Nigeria soils according to Enwezor et al. (2002) was 90:45:45 kg NPK ha- ${ }^{-1}$. However, in sawah rice based production system, minimum fertilizer rate of 30:15:15 kg NPK ha ${ }^{-1}$ in both cropping seasons gave similar grain yield with 90:45:45 $\mathrm{kg} \mathrm{NPK} \mathrm{ha}^{-1}$.

The performance of ratooned rice in terms of plant height, chlorophyll content, panicle length, panicles weight, number of grains panicle ${ }^{-1}$ and grain yield on the previous fertilizer treated plots were similar (Table 2). This further confirms the potential of sawah rice based production systems. However, the application of urea fertilizer had influence on the ratooned rice. The $0 \mathrm{~kg} \mathrm{~N} \mathrm{ha}^{-1}$ had the shortest plant with the lowest chlorophyll content. The grain yields of the various $\mathrm{N}$-fertilizer plots were similar although the grain yield obtained from $0 \mathrm{~kg} \mathrm{~N}$ fertilizer appeared to be appreciably low. This is an indication that $0 \mathrm{~kg} \mathrm{~N} \mathrm{ha}^{-1}$ would not be supporting high productivity as reflected by the lower plant height and chlorophyll content of the leaves $(p>0.5)$. But a minimal rate of $30 \mathrm{~kg} \mathrm{~N} \mathrm{ha}^{-1}$ gave maximum grain yields which seem to be sufficient to support the ratooned rice comparable to $90 \mathrm{~kg} \mathrm{~N} \mathrm{ha}^{-1}$. Oad and Ponpe (2001) reported a maximum grain yield at $60 \mathrm{~kg} \mathrm{~N} \mathrm{ha}^{-1}$ in irrigated field.

Table 2. Effect of fertilizer on lowland rice and ratooned rice in sawah production system in the inland valley

\begin{tabular}{|c|c|c|c|c|c|c|}
\hline & $\begin{array}{l}\text { Plant height } \\
(\mathrm{cm})\end{array}$ & $\begin{array}{l}\text { Chlorophyll } \\
\text { content }\end{array}$ & $\begin{array}{l}\text { Panicle } \\
\text { length }(\mathrm{cm})\end{array}$ & $\begin{array}{l}\text { Panicles wt } \\
(\mathrm{gm})\end{array}$ & $\begin{array}{l}\text { No. of grains } \\
\text { panicle }^{-1}\end{array}$ & $\begin{array}{l}\text { Grain yield } \\
\left(\mathrm{t} \mathrm{ha}^{-1}\right)\end{array}$ \\
\hline \multicolumn{7}{|c|}{$\begin{array}{l}\text { Lowland rice } \\
\text { (L) }\end{array}$} \\
\hline $30: 15: 15$ & 107.7 & 37.34 & 22.12 & 1.64 & 142 & 1.75 \\
\hline $45: 22.5: 22.5$ & 96.7 & 37.68 & 21.37 & 1.62 & 129 & 1.46 \\
\hline $60: 30: 30$ & 102.3 & 37.63 & 22.36 & 1.63 & 121 & 1.58 \\
\hline $90: 45: 45$ & 101.7 & 39.68 & 21.98 & 1.55 & 132 & 1.30 \\
\hline LSD & 11.12 & 3.29 & 1.19 & 0.39 & 23.3 & 0.479 \\
\hline \multicolumn{7}{|c|}{$\begin{array}{l}\text { Ratooned rice } \\
\text { (R) }\end{array}$} \\
\hline 0 & 96.8 & 33.14 & 21.86 & 1.65 & 126 & 1.39 \\
\hline 30 & 101.5 & 35.45 & 22.11 & 1.67 & 135 & 1.62 \\
\hline 60 & 101.1 & 40.18 & 21.84 & 1.47 & 136 & 1.58 \\
\hline 90 & 108.9 & 43.56 & 22.01 & 1.64 & 127 & 1.50 \\
\hline LSD & 9.27 & 1.91 & 1.06 & 0.32 & 19.92 & 0.475 \\
\hline$L \times R$ & NS & NS & $\mathrm{S}$ & NS & NS & NS \\
\hline $\mathrm{CV}$ & 9.33 & 5.15 & 4.98 & 20.36 & 15.61 & 24.44 \\
\hline
\end{tabular}

$\mathrm{NS}=$ Not significant, $\mathrm{S}=$ significant. 
Table 3. Effect of residual fertilizer on okra performance in Sawah lowland ratooned rice-okra sequence in inland valley

\begin{tabular}{|c|c|c|c|c|c|c|c|c|c|c|}
\hline \multirow{3}{*}{ Treatment } & \multicolumn{2}{|c|}{$\begin{array}{c}\text { Plant height @ } 10 \\
\text { WAS (cm) }\end{array}$} & \multicolumn{2}{|c|}{$\begin{array}{c}\text { Chlorophyll content } \\
\text { @ } 10 \mathrm{WAS}\end{array}$} & \multicolumn{2}{|c|}{$\begin{array}{c}\text { Number of leaves } @ \\
10 \text { WAS }\end{array}$} & \multicolumn{2}{|c|}{ Number of pod } & \multicolumn{2}{|c|}{ Pod weight $\left(\mathrm{kg} \mathrm{ha}^{-1}\right)$} \\
\hline & $2010 / 20$ & $2011 / 20$ & $2010 / 20$ & $2011 / 20$ & $2010 / 20$ & $2011 / 20$ & $2010 / 20$ & $2011 / 20$ & $2010 / 20$ & $2011 / 20$ \\
\hline & 11 & 12 & 11 & 12 & 11 & 12 & 11 & 12 & 11 & 12 \\
\hline \multicolumn{11}{|l|}{ NPK } \\
\hline $30: 15: 15$ & 107.77 & 101.42 & 37.10 & 40.11 & 21.33 & 22.23 & 66.42 & 68.90 & 1776 & 1567 \\
\hline $\begin{array}{l}45: 22.5: 2 \\
2.5\end{array}$ & 101.80 & 100.92 & 36.24 & 39.98 & 24.83 & 24.09 & 91.75 & 79.00 & 2490 & 1650 \\
\hline $60: 30: 30$ & 106.48 & 102.01 & 38.18 & 41.01 & 25.00 & 24.65 & 60.50 & 68.01 & 1762 & 1908 \\
\hline $90: 45: 45$ & 97.75 & 103.34 & 35.08 & 42.10 & 27.50 & 25.08 & 52.42 & 66.01 & 1487 & 1508 \\
\hline LSD & NS & NS & NS & NS & NS & NS & 18.47 & NS & 766.06 & NS \\
\hline \multicolumn{11}{|l|}{ UREA } \\
\hline 0 & 97.22 & 99.05 & 35.21 & 39.04 & 22.33 & 23.21 & 55.83 & 62.09 & 1584 & 1578 \\
\hline 30 & 95.17 & 98.21 & 35.48 & 39.40 & 22.25 & 22.98 & 64.92 & 64.01 & 1839 & 1610 \\
\hline 60 & 107.00 & 102.30 & 37.52 & 38.98 & 24.58 & 23.56 & 70.83 & 61.09 & 1954 & 1590 \\
\hline 90 & 114.42 & 112.00 & 38.35 & 40.05 & 28.50 & 24.10 & 79.50 & 63.02 & 2139 & 1612 \\
\hline LSD & 7.54 & NS & 1.78 & NS & 1.67 & NS & 5.87 & NS & 228.82 & NS \\
\hline
\end{tabular}

$\mathrm{WAS}=$ Weeks after sowing; NS= Not significant.

The grain yield (1.39-1.62 $\mathrm{t} \mathrm{ha}^{-1}$ ) obtained from ratooned rice alone is comparable to the obtainable yield in the upland ecology per annual. The overall grain yield from the two crops of rice ranged between 4.47 and $5.65 \mathrm{t}$ $\mathrm{ha}^{-1}$ year $^{-1}$ compared to single cropping.

The pooled plant heights of okra at 10 WAS, obtained in the previous plots main lowland rice treated with NPK fertilizer were not significantly different from each other. However, the plant height observed in previous plot of ratooned rice treated with $\mathrm{N}$-fertilizer plots in 2010/2011, were significantly different from each other. The previous ratooned rice plots that received $90 \mathrm{~kg} \mathrm{~N}^{-1}$ had the tallest plant while the plots that received zero level and $30 \mathrm{~kg} \mathrm{~N} \mathrm{ha}^{-1}$ which were similar, had the shortest plants. The chlorophyll content of okra observed in ratooned rice plots that received 60 and $90 \mathrm{~kg} \mathrm{~N} \mathrm{ha}^{-1}$ was higher than those of zero and $30 \mathrm{~kg} \mathrm{~N} \mathrm{ha}^{-1}$. This is an indication that $60 \mathrm{~N} \mathrm{~kg} \mathrm{ha}^{-1}$ applied to the preceding ratooned rice is capable of producing similar leaf greenness comparable to $90 \mathrm{~N} \mathrm{~kg} \mathrm{ha}^{-1}$. The pooled number of okra pod obtained from plots of lowland rice that received NPK 45:22.5:22.5 were higher than those of NPK 30:15:15, 60:30:30 and 90:45:45. However, number of pods obtained from previous ratooned rice increases as $\mathrm{N}$-fertilizer levels increases. However, collective pod weight obtained from 90:45:45 NPK kg ha ${ }^{-1}$ plots of lowland rice was significantly lower than 45:22.5:22.5 NPK kg ha but had a similar fresh pod weight with $30: 15: 15$ and 60:30:30 NPK kg ha ${ }^{-1}$. The preceding ratooned rice plots treated with $\mathrm{N}$-fertilizer level of $60 \mathrm{~N} \mathrm{~kg} \mathrm{ha}^{-1}$ had similar pod yield with both 30 and 90 . However, the preceding plot ratooned rice treated with $\mathrm{N}$-fertilizer level of $90 \mathrm{~N} \mathrm{~kg} \mathrm{ha}^{-1}$ had significantly higher pod weight than $30 \mathrm{~N} \mathrm{~kg}$ $\mathrm{ha}^{-1}$.

The fresh pod weight of okra obtained from the pooled fertilizer treated preceding lowland rice plots of 30:15:15 NPK ha ${ }^{-1}$ and $60 \mathrm{~N} \mathrm{~kg} \mathrm{ha}^{-1}$ of the preceding ratooned rice plot appeared to better. The greenness of okra leaf in the preceding lowland rice and ratooned rice plots also corroborate this fact.

Based on this study, minimal rate of $30: 15: 15 \mathrm{~kg} \mathrm{NPK} \mathrm{ha}^{-1}$ fertilizer could be adequate to complement the benefit accruable to sawah rice production systems to produce maximum grain yield for the main lowland rice. It also shows that ratooned rice crop treated with $60 \mathrm{~N} \mathrm{~kg} \mathrm{ha}^{-1}$ fertilizer could produce maximum grain yield $\left(1.58 \mathrm{t} \mathrm{ha}^{-1}\right)$ that is equal to the obtainable yield in the upland ecology and as well enhanced the productivity of the succeeding okra. The overall grain yield of rice ranged between 4.47 and $5.65 \mathrm{t} \mathrm{ha}^{-1}$ year $^{-1}$ was achieved in sawah rice based production system of the inland valley with minimal resources that is affordable by the resource poor 
farmers. This is pointer to the fact that triple cropping in sawah rice based production system will enhance the productivity of inland valley with minimal fertilizer application.

\section{Acknowledgement}

The authors wish to appreciate Kinki University, Japan for providing the fund and power tiller for the Project.

\section{References}

Adigbo, S. O., Okeleye, K. A., \& Adigbo, V. B. (2007). Performance of upland rice fitted into Lowland rice-vegetable/cowpea sequence in rainfed inland valley. Agronomy Journal, 99, 377-383. http://dx.doi.org/10.2134/agronj2005.0170

Adigbo, S. O., Olojede, M. O., Harris, P. J. C., \& Ajayi, O. (2012). Ratooned lowland NERICA rice varieties as an option for triple cropping in inland valleys of derived savannah in Nigeria. Experimental Agriculture, 48(4), 551-562. http://dx.doi.org/10.1017/S0014479712000452

Adigbo, S. O., Ojerinde, A. O., Ajayi, O., \& Nwilene, F. E. (2010). Effects of Sowing Methods on Upland Rice in Lowland Rice-Vegetable Sequence in Inland Valley. Journal of Agricultural Science and Technology, 4(3), 1-10.

African Rice Center (WARDA)/FAO/SAA. (2008). In E. A. Somado, R. G. Guei, \& S. O. Keya (Eds.), $N_{E R I C A}$ : the new rice for Africa-a compendium (p. 210). Cotonou, Benin: Africa Rice Center (WARDA); Rome, Italy: FAO; Tokyo, Japan: Sasakawa Africa Association.

Africa Rice Center (WARDA). (2008). Africa Rice Trends (2007) (p. 84). Cotonou, Benin: Africa Rice Center (WARDA).

Buri, M. M., Issaka, R. N., \& Wakatsuki, T. (2007). The sawah technology of rice production for lowlands: An effective tool for poverty alleviation in Southern Ghana. Paper presented at the $4^{\text {th }}$ international conference of the Africa soil science society organized at the Ghana Institute of Management and Public Administration (GIMPA), Accra, Ghana from 7th-13th January, 2007.

Enwezor, W. O., Udo, E. J., Usoroh, N. J., Ayotade, K. A., Adepetu, J. A., Chude, V. O., \& Udegbe, C. I. (2002). Fertilizer use and management practices for crops in Nigeria series no. 2 (pp.15-18). Ibadan: Bobma publisher.

Hirose, S., \& Wakatsuki, T. (2002). Restoration of inland valley ecosystems in West Africa. Norin Tokei Kyokai, Tokyo.

Jason, B., James, P. L., \& Ronald, P. R. (2005). Fertilization of ratoon rice in Louisiana State University. Journal of Crop Science, 53(2), 10-15.

Kyuma, K. (2003). Paddy Soil Science. Kyoto University Press.

Oad, F. C., \& Ponpe, S. C. (2001). Yield attributes of conventional rice ratoonings and lock lodged ratooning under varying nitrogen levels. Sindh Agriculture University Tando Jam. Philippines Rice Reasearch Institute (PhilRice), 1(3), 356-358.

Wakatsuki, T., \& Masuanga, T. (2005). Ecological Engineering for Sustainable Food Production and the Restoration of Degraded Watersheds in Tropics of low pH Soils: Focus on West Africa. Soil Sci. Plant Nutr., $51,629-636$

Wakatsuki, T., Buri M. M., \& Fashola, O. O. (2005). Ecological engineering for sustainable rice production and the restoration of degraded watersheds in West Africa. In Proceedings of rice research conference, IRRI (pp 336-366). http://dx.doi.org/10.1111/j.1747-0765.2005.tb00079.x

West African Rice Development Association (WARDA). (2000). "The Nigerian Rice Economy in a Competitive World: Constraints, Opportunities and Strategic Choices", Concept Note Submitted to USAID. 